\section{(2) OPEN ACCESS}

\title{
Lung cancer and end-of-life care: a systematic review and thematic synthesis of aggressive inpatient care
}

\section{Olivier Bylicki 이 , ${ }^{1}$ Morgane Didier, ${ }^{2}$ Frederic Riviere, ${ }^{1}$ Jacques Margery, ${ }^{1}$ Frederic Grassin, ${ }^{1}$ Christos Chouaid ${ }^{2}$}

- Additional material is published online only. To view, please visit the journal online (http://dx.doi.org/10.1136/ bmjspcare-2019-001770)

${ }^{1}$ Pneumologie, Hopital d'Instruction des Armees Percy, Clamart, France

${ }^{2}$ Service de Pneumologie, Centre Hospitalier Intercommunal de Creteil, Creteil, France

\section{Correspondence to} Dr Olivier Bylicki, Pneumologie, Hopital d'Instruction des Armees Percy, Clamart 92141, France; bylicki.olivier@yahoo.fr

Received 19 January 2019 Revised 30 July 2019 Accepted 14 August 2019 Published Online First 31 August 2019

\section{Check for updates}

(C) Author(s) (or their employer(s)) 2019. Re-use permitted under CC BY-NC. No commercial re-use. See rights and permissions. Published by BMJ.

To cite: Bylicki O, Didier M, Riviere $\mathrm{F}$, et al. BMJ

Supportive \& Palliative Care 2019:9:413-424.

\section{ABSTRACT}

Objectives Despite recent advances in thoracic oncology, most patients with metastatic lung cancer die within months of diagnosis. Aggressiveness of their end-of-life (EOL) care has been the subject of numerous studies. This study was undertaken to evaluate the literature on aggressive inpatient EOL care for lung cancer and analyse the evolution of its aggressiveness over time.

Methods A systematic international literature search restricted to English-language publications used terms associated with aggressiveness of care, EOL and their synonyms. Two independent researchers screened for eligibility and extracted all data and another a random $10 \%$ sample of the abstracts. Electronic Medline and Embase databases were searched (2000-20 September 2018). EOLcare aggressiveness was defined as follows: 1) chemotherapy administered during the last 14 days of life ( $D O L)$ or new chemotherapy regimen during the last $30 \mathrm{DOL} ; 2$ ) >2 emergency department visits; 3) >1 hospitalisation during the last $30 \mathrm{DOL}$; 4) ICU admission during the last $30 \mathrm{DOL}$ and 5) palliative care started $<3$ days before death.

Results Among the 150 articles identified, 42 were retained for review: 1 clinical trial, 3 observational cohorts, 21 retrospective analyses and 17 administrative data-based studies. The percentage of patients subjected to aggressive therapy seems to have increased over time. Early management by palliative care teams seems to limit aggressive care.

Conclusions Our analysis indicated very frequent aggressive EOL care for patients with lung cancer, regardless of the definition used. The extent of that aggressiveness and its impact on healthcare costs warrant further studies.

\section{INTRODUCTION}

Lung cancer is the most common cancer worldwide, with 1.8 million new cases reported in 2012. Tobacco smoking, including second-hand and third-hand smoke exposure, remains the major risk factor for lung cancer. ${ }^{12}$ The lung cancer prognosis is generally poor, with 5 -year overall survival (OS) estimated at 10\%-15\% worldwide. In France, respective 5-year and 10-year survival rates in 2015 were $17 \%$ and $10 \%$. Lung cancer's poor prognosis can be explained by its diagnosis at an advanced stage, despite recent progress made in screening. In 2012, about 1.6 million lung cancer deaths were reported worldwide, making it the leading cause of death due to cancer for men and the second for women after breast cancer. ${ }^{3-6}$ Over the past 10 years, management of patients with lung cancer, especially non-small cell lung cancer (NSCLC), benefited from the development of targeted therapies for patients with addictive mutation(s) and immunecheckpoint inhibitors. $^{7-10}$ Although those advances prolonged OS, the large majority of patients with lung cancer will die of the disease during the 5 years following its diagnosis.

However, those new treatments, which have increased the number of therapeutic options, render management of the end-of-life (EOL) period more complex. ${ }^{11}$ Over the past few years, several teams examined the EOL period, specifically focusing on the factors that can negatively impact it. $^{11-14}$ Appropriate and reasonable use of active agents against solid tumours during this period poses numerous problems in clinical practice: no 


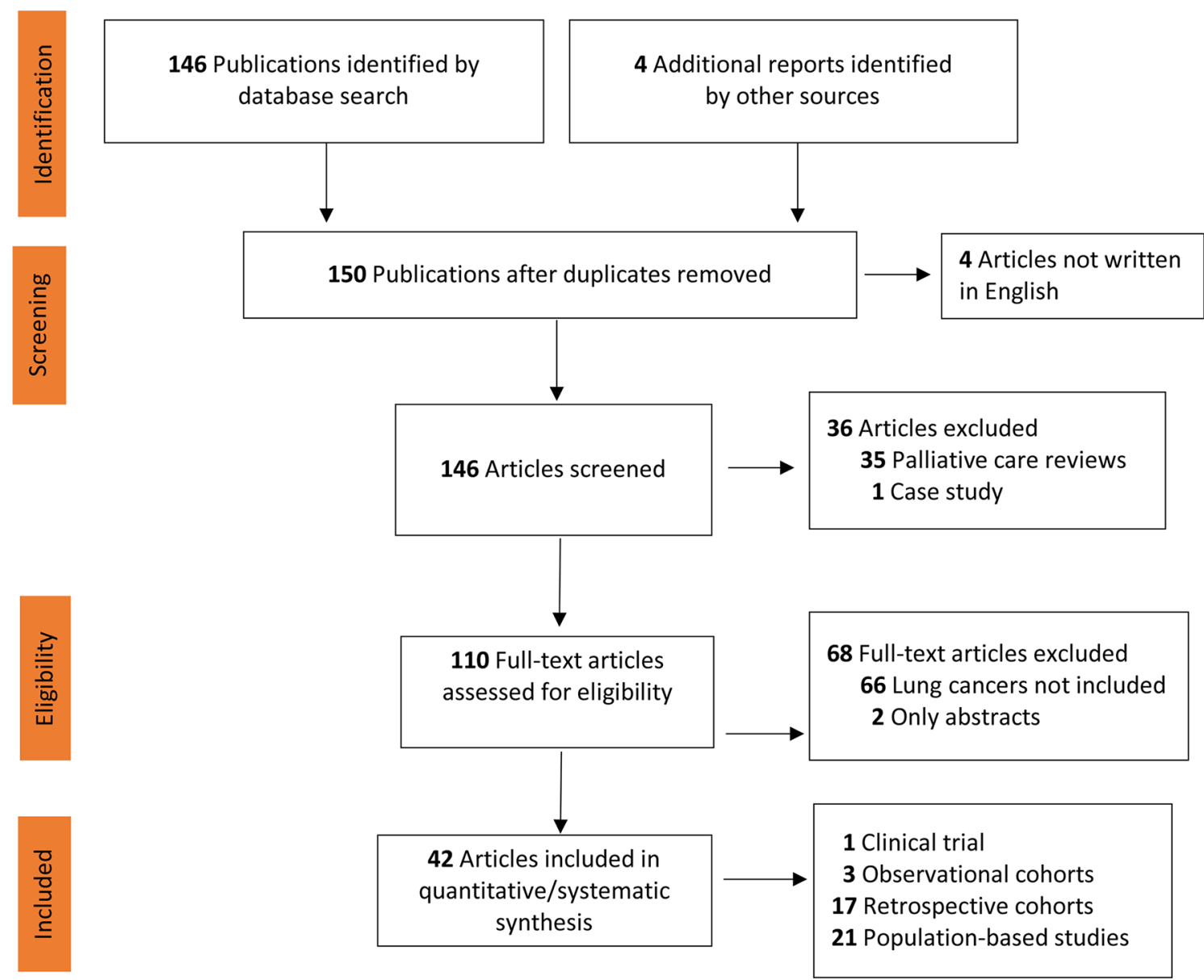

Figure 1 Preferred Reporting Items for Systematic Reviews and Meta-Analyses flow chart of article identification and selection. Other sources: references of selected articles identified four studies written in Spanish or Japanese.

precise definition of the EOL period exists, it is often difficult to accurately evaluate an individual's life expectancy and defining the concept of aggressiveness-of-care is not easy.

During the 2000 s, Earle et al ${ }^{15}$ proposed a series of claims-based quality indicators that measure the aggressiveness of cancer care, including: intensive care unit (ICU) admission during the last months of life, repeated hospitalisations, late or no referral to palliative care and patients given chemotherapy during the last 14 days of life (DOL). The National Quality Forum (NQF) and American Society of Clinical Oncology (ASCO) jointly validated those indicators. ${ }^{11}{ }^{15-20}$ The NQF-ASCO EOL-care items have been integrated into ASCO's Quality Oncology Practice Initiative. ${ }^{1821}$ However, data on those indicators of EOL-care aggressiveness vary widely from one country to another, one type of cancer to another and the organisation of that care.

This systematic review was conducted to synthesise all available information about aggressiveness of EOL care for those with cancer, focusing on lung cancer. The economic impact of aggressive EOL care was also evaluated.

\section{METHODS}

A systematic review was conducted and reported in accordance with the Preferred Reporting Items for Systematic Reviews and Meta-Analyses (PRISMA). ${ }^{22}$

\section{Search strategy}

The preplanned search strategy is delineated in the PRISMA flow chart (figure 1). Medline and Embase (both 2000-September 2018) databases were subjected to an exhaustive search for publications using the following terms: (aggressiveness), (Aggressive) (End of Life), (Lung cancer), (Lung neoplasm), (NSCLC), (Lung tumors), (palliative care) and (supportive care). Each full abstract was initially read and only those analysing EOL-care aggressiveness for patients with cancer were retained. That step identified 150 references. The second step was restricted to articles analysing - at least in part-lung cancers, excluding case reports and general reviews; it found 42 publications examining one or several indicators of EOL-care aggressivity of patients with lung cancer that were read in their entirety. $11141623-65$

\section{Study selection}

Study abstracts, titles and full texts, when appropriate, were screened independently by two reviewers (OB 
and CC) for conformity with the inclusion and exclusion criteria. A third author (FG) redid the search and $10 \%$ of the abstracts were randomly selected to see if he selected the same studies as the other two.

Inclusion criteria were: patients with lung cancer enrolled in the study and at least one of the six aggression factors validated by Earle et $a l^{15}$ was assessed. Exclusion criteria were: any literature review, congress abstracts without subsequent publications, studies that did not evaluate aggression factors and articles not published in English.

Any discrepancies unresolved by discussion between reviewers were adjudicated by a third reviewer (MD). Studies satisfying the selection criteria were retrieved and their full texts were analysed.

\section{Data extraction}

One reviewer (OB) recorded all information and available data on a dedicated data-extraction form.

\section{Analysis}

A summary, including descriptions, comparisons and limitations of each EOL-care indicator, was made. Study heterogeneity concerning populations, interventions, comparators and outcomes proscribed metaanalysis of combined data. Should another criterion of EOL-care aggressiveness be identified and reported by a substantial number of articles, it will be included in our systematic review.

\section{RESULTS}

\section{Selected studies}

Among 146 identified titles, 42 papers (1 clinical trial, 3 observational cohorts, 21 retrospective analyses and 17 administrative data-based studies) meeting the eligibility criteria are summarised in online supplementary appendix table S1.

\section{Chemotherapy during the last $30 \mathrm{DOL}$}

Because this indicator was the most studied, its impact on management is the best known (table 1). It was evaluated according to three modalities ${ }^{111516}$ : the percentages of patients receiving chemotherapy during the last 14 or $30 \mathrm{DOL}$ or starting a new chemotherapy line during the last 30 DOL. During our systematic search, we identified the criterion of chemotherapy during the last 30 days, which was frequently mentioned in the most recent studies, and added it to our criteria. That situation was examined in one study from $1996^{11}$ on patients with solid tumours: $4.9 \%$ of patients in 1993 and 5.7\% in 1996 started a new treatment line during the last 30 DOL. For this item, most publications were based on retrospective populations or analyses of administrative data. Nine papers concerned only patients with lung cancer; the others had cancers affecting various organs.

The percentages of patients given chemotherapy during the last 14 DOL ranged from $1 \%$ to $23.8 \%$ and $6.4 \%$ to $>50 \%$ received it during the last 30 DOL. Those rates also varied widely among countries with similar healthcare systems for patients with lung cancer during the last 30 DOL: $5.7 \%$ in Norway, $5.9 \%$ in Canada, $12.1 \%$ in the USA and $>16 \%$ in the Netherlands and Germany. ${ }^{49}$ Those variations can be explained by the different healthcare systems, payment organisations and cultural and societal considerations, notably in northern Europe.

Factors associated with administering EOL chemotherapy

Young age was identified among the factors explaining a high EOL-chemotherapy rate, regardless of tumour type, in several studies. ${ }^{5365-69}$ By contrast, no consistent association was found among these studies between sex and tendency to administer EOL chemotherapy. ${ }^{66} 70$ Considerable differences associated with the doctors managing these patients were also found ${ }^{69} 71$; the feeling of professional failure, uselessness and frustration and stress linked to their private lives impacted the pursuance of active EOL treatments. Active EOL therapies were also administered to a higher percentage of patients with lung cancer without comorbidities, with high socioeconomic status and for those with anxiety or depressive profiles. ${ }^{294072}$

Some factors were also associated with the organisation of healthcare systems. ${ }^{48}$ Early introduction of palliative care increased the median time between the last chemotherapy dose and death (64 vs 40.5 days; $\mathrm{p}=0.02$ ), and patients received less chemotherapy during the last 60 DOL $(52.5 \%$ vs $70.1 \% ; \mathrm{p}=0.05)$, after adjustment for age, sex and Eastern Cooperative Oncology Group performance status (ECOG PS). ${ }^{34}$

Access to palliative care near the patient's home or in the hospital where the patient is managed was associated with a lower rate of active treatments during the last 30 DOL. ${ }^{6673}$ However, not being provided information on palliative care units 2 weeks before death was an independent risk factor for a shorter interval between the end of chemotherapy and death. ${ }^{70}$

Other parameters were described less frequently as being associated with near-death chemotherapy: symptomatic disease, poor ECOG PS, dying in a small hospital ( $<1000$ beds). ${ }^{6670}$ On the other hand, to be included in a therapeutic trial did not seem to influence the interval between chemotherapy and death. ${ }^{59}$ Less invasive oral treatments (targeted therapies, chemotherapies), often better tolerated, can easily be maintained at the EOL. ${ }^{74}$ Notably, according to a prospective analysis of patients with lung cancer, oral chemotherapy was the only factor associated with the probability of receiving chemotherapy during the last 14 DOL. ${ }^{75}$ The EOL-chemotherapy rate did not differ significantly according to treatment line ${ }^{51}: 39 \%$ for first line, $28 \%$ for second line and $33 \%$ for third or more line. ${ }^{51}$

The impact of EOL treatment on the quality of care was examined in several studies. ${ }^{34} 41517677$ One 
Table 1 Reports of studies on chemotherapy during the last 30 days of life (DOL)

\begin{tabular}{|c|c|c|c|c|c|}
\hline \multirow[b]{2}{*}{ Study } & \multirow[b]{2}{*}{ Patients, $N$} & \multirow[b]{2}{*}{ Type of cancer } & \multirow[b]{2}{*}{ Inclusion criteria } & \multicolumn{2}{|c|}{$\%$ Receiving chemotherapy during } \\
\hline & & & & Last $30 \mathrm{DOL}$ & Last $14 \mathrm{DOL}$ \\
\hline Rautakorpi et a ${ }^{25}$ & 38982 & All & Any & 16 & 7.2 \\
\hline Falchook et a $\beta^{32}$ & 12765 & Lung & Patients $<65$ years & 12.6 & \\
\hline Ersek et a $\left.\right|^{42}$ & 847 & NSCLC & Any & 30.6 & \\
\hline Wright et al ${ }^{14}$ & 1146 & All & Any & & 6.5 \\
\hline \multirow[t]{7}{*}{ Bekelman et a $/^{49}$} & 389073 & All & USA & 10.6 & \\
\hline & & & The Netherlands & 10.6 & \\
\hline & & & Belgium & 12.7 & \\
\hline & & & Canada & 8.8 & \\
\hline & & & UK & NR & \\
\hline & & & Germany & 10.5 & \\
\hline & & & Norway & 4.8 & \\
\hline \multirow[t]{2}{*}{ Sano and Fushimi ${ }^{45}$} & 26012 & All & Palliative care consultation & & 1.7 \\
\hline & & & SOC & & 4.0 \\
\hline \multirow[t]{2}{*}{ Parekh et $\left.a\right|^{51}$} & 242 & NSCLC & 2009-10 Prepalliative care & & 17.0 \\
\hline & & & 2003-14 Postpalliative care & & 7.0 \\
\hline Pacetti et $a^{\beta^{39}}$ & 2164 & All & Any & 24.3 & \\
\hline \multirow[t]{2}{*}{ Wang et $\left.a\right|^{52}$} & 82242 & All & 2005 & & 4.4 \\
\hline & & & 2009 & & 4.0 \\
\hline \multirow[t]{2}{*}{ Choi et a $\beta^{30}$} & 263 & All & 2002 & 14.0 & 3.5 \\
\hline & & & 2012 & 42.7 & 23.8 \\
\hline Cheung et $a l^{\beta 1}$ & 107253 & All & Any & & 3.6 \\
\hline \multirow[t]{3}{*}{ Lee et $a \beta^{38}$} & 2345 & All & 2000 & 25.7 & \\
\hline & & & 2005 & 32.7 & \\
\hline & & & 2010 & 44.2 & \\
\hline \multirow[t]{2}{*}{ Kok et al ${ }^{27}$} & 266 & NSCLC & $2008-2009$ & & 5.0 \\
\hline & & & $2011-2012$ & & 1.0 \\
\hline Zhang et $a^{63}$ & 118 & NSCLC & Any & 27 & \\
\hline Adam et $a l^{\beta 3}$ & 120 & All & Any & 11.7 & 7.6 \\
\hline Sesé et $a /^{35}$ & 94 & Lung & Any & 55 & 22 \\
\hline \multirow[t]{2}{*}{ Amano et $a l^{58}$} & 266 & All & Early palliative care & 17 & \\
\hline & & & SOC & 23 & \\
\hline \multirow[t]{2}{*}{ Greer et a ${ }^{29}$} & 151 & NSCLC & SOC & 43.3 & 23.9 \\
\hline & & & Early palliative care & 30.0 & 13.6 \\
\hline Mack et $a /^{46}$ & 1231 & NSCLC and colorectal & Any & & 16.0 \\
\hline Näppä et $a l^{40}$ & 374 & All & Any & 23 & \\
\hline \multirow[t]{2}{*}{ Gonsalves et al ${ }^{44}$} & 200 & All & 2002 & 5 & \\
\hline & & & 2008 & 18 & \\
\hline \multirow[t]{2}{*}{ Ho et $\left.a\right|^{37}$} & 227161 & All & 1993 & & 2.02 \\
\hline & & & 2003 & & 2.9 \\
\hline Andreis et a $\left.\right|^{59}$ & 102 & All & Any & 16 & 6 \\
\hline \multirow[t]{2}{*}{ Warren et $\left.a\right|^{53}$} & 21633 & All & Patients with OS $<6$ months & 14.8 & 9 \\
\hline & & & Patients with OS $>6$ months & 10.2 & 6.4 \\
\hline \multirow[t]{2}{*}{ Keating et $\left.a\right|^{47}$} & 5826 & NSCLC and colorectal & VHA cohort & & 4.6 \\
\hline & & & SEER cohort & & 7.5 \\
\hline Kao et $a^{62}$ & 747 & All & Any & 18 & 8.0 \\
\hline Hashimoto et al ${ }^{55}$ & 255 & All & Any & 12.6 & 3.10 \\
\hline Tang et $a l^{28}$ & 242530 & All & Trend 2000-2006 & 16.2 & \\
\hline Barbera et $\left.a\right|^{34}$ & 5855 & All & Any & & 4.6 \\
\hline \multirow[t]{2}{*}{ Earle et al ${ }^{11}$} & 215484 & All & 1993 & & 9.70 \\
\hline & & & 1999 & & 11.6 \\
\hline Temel et al ${ }^{\beta 6}$ & 46 & NSCLC & Integrated palliative care & 40 & 23 \\
\hline
\end{tabular}




\begin{tabular}{|c|c|c|c|c|c|}
\hline \multirow[b]{2}{*}{ Yun et a $\left.\right|^{54}$} & \multirow[b]{2}{*}{3750} & \multirow[b]{2}{*}{ All } & \multirow[b]{2}{*}{ Any } & \multicolumn{2}{|c|}{$\%$ Receiving chemotherapy during } \\
\hline & & & & 30.9 & 22.5 \\
\hline Murillo and Koeller ${ }^{41}$ & 417 & NSCLC & Any & 43 & 20.0 \\
\hline \multirow[t]{2}{*}{ Earle et $a l^{16}$} & 28777 & All & 1993 & & 13.8 \\
\hline & & & 1996 & & 18.5 \\
\hline Giorgi et a $\left.\right|^{57}$ & 193 & All & Any & 33 & \\
\hline \multirow[t]{2}{*}{ Emanuel et a/ ${ }^{48}$} & 7919 & All & Massachusetts & 9 & \\
\hline & & & California & 9 & \\
\hline Aragon-Ching et $a l^{56}$ & 144 & All & Any & 26 & \\
\hline
\end{tabular}

compared three patient groups: no chemotherapy, conventional chemotherapy but not during the last 14 DOL and late chemotherapy including during the last 14 DOL. ${ }^{76}$ The late chemotherapy group had significantly shorter survival after starting palliative care, was hospitalised more frequently, a documented decision to stop treatment was received less often and patients died more frequently in the hospital. Although receiving chemotherapy prolonged OS by 2 months (OR 1.26, 95\% CI 1.20 to $1.32 ; \mathrm{p}<0.001$ ), compared with not receiving it, no survival difference was found between conventional and late chemotherapy groups. Those authors concluded the absence of any benefit of aggressive EOL management.

Among the factors able to lower the percentage of patients receiving chemotherapy during the last 30 DOL, the impact of early access to a palliative care strategy was explored in several studies. In a monocentric, randomised trial that included 151 patients with advanced NSCLCs over 3 years, early access to palliative care declined non-significantly and lower percentages of patients were given chemotherapy during the last $30 \mathrm{DOL}(30 \%$ vs $43.3 \%$; $\mathrm{p}=0.14$ ) and last $14 \mathrm{DOL}$ $(13.6 \%$ vs $23.6 \%, p=0.18)$. The failure to reach significance probably reflects the too small number of patients recruited. ${ }^{73}$ Despite the lighter therapeutic pressure during the EOL period in that study, an OS benefit was observed for the early palliative care group (11.6 vs 8.9 months, $\mathrm{p}=0.02) .^{65}$

Similarly, an analysis of Japanese administrative data from patients with cancer aged $>65$ years showed that early access to palliative care consultations lowered, from $4 \%$ to $1.5 \%$, the number of patients receiving chemotherapy doses during the last $14 \mathrm{DOL}^{45}$ In contrast, again in Japan, the use of an aggregated aggressivenessof-care criterion at the EOL to compare 54 patients seen in palliative care consultations $>3$ months before their deaths vs 211 patients without such appointments revealed improved quality of life but did not significantly lower the rate of patients who had received chemotherapy during the last $14 \mathrm{DOL}$; that lack of significance could also be attributable to the small sample size. ${ }^{58}$
Repeated emergency department visits during the last 30 DOL

This criterion was analysed in 38\% of the articles retained (table 2) and concerned 1.8\%-66.9\% of the patients. Three studies, one prospective, addressed only patients with lung cancer. ${ }^{36} 6578$ Early access to palliative care seemed to lower the number of repeated ED consultations. Temel et al, based on 46 patients, evaluating early palliative care management versus standard of care (SOC) found the former (10\%) had fewer repeated ED visits. ${ }^{36}$ That access in global management seems to allow patients and their entourage time to reflect on the prognosis, disease evolution and EOL organisation.

Factors associated with ED visits during the last $30 \mathrm{DOL}$

A meta-analysis of ED visits during the last $30 \mathrm{DOL}$ included 30 studies and 1181842 patients with cancer (including haemopathies). ${ }^{7980}$ Factors significantly associated with ED visits were male sex (OR 1.24, 95\% CI 1.19 to 1.29 ), African origin (OR 1.45, 95\% CI 1.40 to 1.50$)$, lung cancer (OR $1.17,95 \%$ CI 1.10 to 1.23 ) and low socioeconomic level (OR 1.15, 95\% CI 1.10 to 1.19$)$. In contrast, patients receiving palliative care had fewer ED consultations (OR 0.43, 95\% CI 0.36 to $0.51])$.

Among symptoms associated with ED visits, dyspnoea and pain were the most common. ${ }^{81}$ The percentage of EOL patients consulting the ED seems to have increased over time. ${ }^{1628} 37$ In a populationbased, retrospective, cohort study using 1993-2003 administrative data from 227161 patients with cancer, multiple ED visits increased significantly over time from $8.60 \%$ to $10.53 \% .{ }^{37}$ Factors associated with that rise were young age, male sex and rural residence.

Study results also suggest that many emergency medicine specialists feel underqualified to manage these EOL patients, which might explain the high number of ED visits. $^{82-86}$

\section{Repeated hospitalisations during the last $30 \mathrm{DOL}$}

This indicator was analysed in $11(26 \%)$ of the 42 articles retained for this synthesis (table 3 ). As a function of the study and country, $3.6 \%$ to $>50 \%$ of the patients 
Table 2 Studies reports of repeated end-of-life emergency department (ED) consultation

\begin{tabular}{|c|c|c|c|c|}
\hline Study & $\begin{array}{l}\text { Patients, } \\
N\end{array}$ & $\begin{array}{l}\text { Type of } \\
\text { cancer }\end{array}$ & $\begin{array}{l}\text { Inclusion } \\
\text { criteria }\end{array}$ & $\begin{array}{l}\geq 1 \mathrm{ED} \\
\text { visit (\%) }\end{array}$ \\
\hline Ersek et al/2 & 847 & NSCLC & Any & 66.90 \\
\hline Falchook et al ${ }^{\beta 2}$ & 12765 & Lung & $\begin{array}{l}\text { Patient }<65 \\
\text { years }\end{array}$ & 1.8 \\
\hline \multirow[t]{2}{*}{ Wu et $a l^{23}$} & \multirow[t]{2}{*}{49920} & \multirow[t]{2}{*}{ All } & $\begin{array}{l}\text { Palliative } \\
\text { chemotherapy } \\
<6 \text { months }\end{array}$ & 34 \\
\hline & & & $\begin{array}{l}\text { Any } \\
\text { chemotherapy }\end{array}$ & 13.7 \\
\hline Henson et al ${ }^{43}$ & 681 & All & Any & 29.70 \\
\hline Wright et al ${ }^{14}$ & 1146 & All & Any & 7.90 \\
\hline \multirow[t]{2}{*}{ Wang et $a^{52}$} & \multirow[t]{2}{*}{82242} & \multirow[t]{2}{*}{ All } & 2005 & 34 \\
\hline & & & 2009 & 32.90 \\
\hline \multirow[t]{2}{*}{ Choi et $\left.a\right|^{30}$} & \multirow[t]{2}{*}{263} & \multirow[t]{2}{*}{ All } & 2002 & 22.8 \\
\hline & & & 2012 & 74.8 \\
\hline Cheung et $a l^{\beta 1}$ & 107253 & All & Any & 14.7 \\
\hline \multirow[t]{2}{*}{ Amano et al ${ }^{58}$} & \multirow[t]{2}{*}{266} & \multirow[t]{2}{*}{ All } & $\begin{array}{l}\text { Early palliative } \\
\text { care }\end{array}$ & 11 \\
\hline & & & SOC & 4.70 \\
\hline Mack et a/46 & 1231 & $\begin{array}{l}\text { NSCLC and } \\
\text { colorectal }\end{array}$ & Any & 40 \\
\hline \multirow[t]{2}{*}{ Ho et $a l^{37}$} & \multirow[t]{2}{*}{22761} & \multirow[t]{2}{*}{ All } & 1993 & 8.60 \\
\hline & & & 2003 & 10.50 \\
\hline \multirow[t]{2}{*}{ Gonsalves et al ${ }^{44}$} & \multirow[t]{2}{*}{200} & \multirow[t]{2}{*}{ All } & 2002 & 6 \\
\hline & & & 2008 & 9 \\
\hline \multirow[t]{2}{*}{ Keating et $a l^{47}$} & \multirow[t]{2}{*}{5826} & \multirow{2}{*}{$\begin{array}{l}\text { NSCLC and } \\
\text { colorectal }\end{array}$} & VHA cohort & 13.10 \\
\hline & & & SEER cohort & 14.70 \\
\hline Tang et $\left.a\right|^{28}$ & 242530 & All & $\begin{array}{l}\text { Trend 2000- } \\
2006\end{array}$ & 18.3 \\
\hline Temel et $a l^{36}$ & 46 & NSCLC & $\begin{array}{l}\text { Integrated } \\
\text { palliative care }\end{array}$ & 10 \\
\hline Barbera et $a l^{\beta 4}$ & 5855 & All & Any & 32.20 \\
\hline \multirow[t]{2}{*}{ Earle et $a l^{16}$} & \multirow[t]{2}{*}{28777} & \multirow[t]{2}{*}{ All } & 1993 & 7.20 \\
\hline & & & 1996 & 9.20 \\
\hline
\end{tabular}

ED, emergency department; NSCLC, non-small cell lung cancer; SEER, Surveillance, Epidemiology and End Results; SOC, standard of care; VHA, Veterans Health Administration.

were concerned. For example, 59.3\% of 12764 patients with lung cancer aged $<65$ years were included in analyses based on American medical administrative data. ${ }^{32}$

This dimension of the quality of care during the EOL period was also evaluated with patient hospitalisations for $>14$ days. That rate ranged from $12 \%$ in the USA to $42 \%$ in Taiwan. However, that indicator is difficult to interpret because it is linked to care facilities and payment modalities. ${ }^{11}$

\section{ICU admissions during the last $30 \mathrm{DOL}$}

This parameter was analysed in 20/42 (48\%) of the retained studies and affected $2 \%-30 \%$ of the subjects included (table 4). That rate seems to have increased over time, ${ }^{163437}$ rising from $6 \%$ in 2002 to $33 \%$ in 2008 $(\mathrm{p}=0.001)$ in a study comparing 100 patient deaths during each year in the same institution. ${ }^{44}$
Using the Surveillance, Epidemiology and End Results (SEER)-Medicare data from 132051 patients who died of cancer in 2006-2011, ICU admissions rose from $16.2 \%$ to $21.3 \%(\mathrm{p}<0.001){ }^{52}$ Again, based on $1992-$ 2005 SEER data, more patients with lung cancer were admitted to the ICU. ${ }^{87}$ Among 175756 patients with lung cancer entered in the SEER database and hospitalised for a reason other than surgical tumour resection during the study period, $49373(28 \%)$ had at least one ICU stay. The rate of ICU admissions per 1000 hospitalisations increased over the study period from 140.7 in 1992 to 201.7 in $2005(\mathrm{p}<0.001)$.

Factors associated with ICU admission

Factors associated with ICU admission were young age (OR 0.80 for age $70-74$ years, $95 \%$ CI 0.77 to 0.83 vs OR 1.0 for age $<65$ years), male sex (OR 1.10, 95\% CI 1.07 to 1.12 ), wealthier patients (OR $1.50,95 \%$ CI 1.42 to 1.57 ) and localised disease (OR 0.61 for metastatic disease, $95 \mathrm{CI} 0.59$ to 0.63$).{ }^{87}$ Their ICU admissions increased especially for the category 'intermediate ICU', with a risk ratio of 3.09 (95\% CI 2.78 to 3.44) between 1992 and 2005.

Those factors were also found for a cohort of 412 946 patients with NSCLC entered in the National Institutes of Health database between 1998 and 2014, with ICU admissions rising from $13.3 \%$ in 1998 to $27.9 \%$ in $2014(\mathrm{p}<0.01) .{ }^{61} \mathrm{~A}$ multivariate logistic-regression model retained the following factors as independent predictors of ICU care: age $<65$ years, racial minority (vs white), higher Charlson Comorbidity Index, Medicare or Medicaid insurance (vs private insurance), teaching hospitals and medium or large hospitals (vs small hospitals).

The higher rate of ICU admissions during the last 30 DOL has not been accompanied by an increased number of patients on mechanical ventilation, which has either stabilised or decreased (table 4). ${ }^{28}$ The chemotherapy administration during the last 30 DOL enhances the risk of ICU admission during that period ${ }^{64}$ can be explained by the appearance of new, more effective, therapeutic strategies, which incite doctors to raise the therapeutic pressure. The identification of pejorative factors of short-term evolution should enable better definition of the prognoses of these patients and limit unnecessary ICU admissions. The impact of these ICU admissions on the patient's entourage was examined in a large study based on $>1000$ interviews with families that had lost a member to cancer. ${ }^{14}$ Their satisfaction was significantly lower when the patient had been admitted to the ICU during the last $30 \mathrm{DOL}$, than otherwise. In every case, explanation and understanding of medical decisions by the family improved their satisfaction.

The ICU admission rate was lower, ranging from 1\% to $9 \%$, when patients were managed in structures that have implemented a policy of early access to palliative care. ${ }^{26}{ }^{46}$ In their prospective randomised trial, Temel et al compared standard management with earlier 


\begin{tabular}{|c|c|c|c|c|c|}
\hline Study & $\begin{array}{l}\text { Patients, } \\
N\end{array}$ & Type of cancer & Inclusion criteria & $\begin{array}{l}\geq 1 \text { hospital admissions } \\
(\%)\end{array}$ & $\begin{array}{l}>14 \text { days of hospitalisation } \\
(\%)\end{array}$ \\
\hline Falchook et $a l^{32}$ & 12765 & Lung & Patient $<65$ years & 59.30 & \\
\hline \multirow[t]{2}{*}{ Wu et $a l^{23}$} & 49920 & All & Palliative chemotherapy $<6$ months & 22.8 & 42.3 \\
\hline & & & Any chemotherapy & 24.2 & 43.2 \\
\hline Wright et al ${ }^{14}$ & 1146 & All & Any & 6.10 & \\
\hline \multirow[t]{2}{*}{ Wang et $a^{52}$} & 82242 & All & 2005 & 14.00 & \\
\hline & & & 2009 & 14.80 & \\
\hline Cheung et $a l^{31}$ & 107253 & All & Any & 6.30 & \\
\hline \multirow[t]{2}{*}{ Amano et $a^{58}$} & 266 & All & Early palliative care & 3.70 & 54 \\
\hline & & & SOC & 9 & 8 \\
\hline \multirow[t]{2}{*}{ Gonsalves et a/ ${ }^{44}$} & 200 & All & 2002 & 6 & \\
\hline & & & 2008 & 16 & 38 \\
\hline \multirow[t]{2}{*}{ Ho et $a P^{37}$} & 227161 & All & 1993 & 8.50 & \\
\hline & & & 2003 & 7.50 & \\
\hline Tang et $\left.a\right|^{28}$ & 242530 & All & Trend 2000-2006 & 14.2 & 44.4 \\
\hline Temel et $a l^{36}$ & 46 & NSCLC & Integrated palliative care & 13 & \\
\hline \multirow[t]{2}{*}{ Earle et $a l^{16}$} & 28777 & All & 1993 & & 12.50 \\
\hline & & & 1996 & & 11.60 \\
\hline
\end{tabular}

palliative care and found a significantly lower number of the latter had been admitted to the ICU during the last 30 DOL. ${ }^{657}$ Also, in another study comparing management by palliative care teams for $>3$ months with a shorter time, ICU admissions were 10\%-5.6\% lower. $^{58}$

\section{Late admissions to EOL palliative care}

The absence of palliative care management or its too late initiation, ie $<3$ days before death, has been poorly investigated. Although this indicator, which concerns $6 \%-54 \%$ of the patients, is more difficult to establish and interpret (table 5), its impact on the degree of entourage satisfaction is high.

Factors associated with EOL palliative care

According to a study using Canadian databases, ${ }^{14}$ the families of patients enrolled in hospice $>3$ days before death considered EOL-care quality to be excellent more often than those receiving none or $<3$ days $(58.8 \%$ vs $43.1 \%$, respectively). Families of patients receiving $<3$ days of palliative care were less likely to report patients died in their preferred place $(40.0 \%$ vs $72.8 \%)$. Male sex, high Charlson Comorbidity Index, management by oncologists as opposed to 'organ' specialists and management in a teaching hospital were significantly associated with a higher risk of late admission to palliative care. In contrast, the risk of late access to palliative care was lower for African-Americans, single or divorced individuals and when access to it was available. ${ }^{11}$

\section{Economic impact of EOL-care aggressiveness}

From a societal point of view, patients receiving EOL care considered aggressive have higher healthcare costs than the others (online supplementary appendix table S2).
This overexpenditure was about \$C6000 (\$C18 131 vs $\$ C 12$ 678) based on Canadian administrative data. ${ }^{31} \mathrm{An}$ analysis of EOL costs in seven Western countries found means ranging from US\$3160 in the UK to US\$10 273 in Canada, without EOL lung cancer costs being significantly different from those of other cancers. ${ }^{49}$ EOL care was mainly in hospitals in Belgium, Canada, the UK, Germany and Norway, compared with the Netherlands and the USA. EOL hospital expenditures were higher in the USA, Norway and Canada, intermediate in Germany and Belgium, and lower in the Netherlands and the UK.

One study used the American SEER-Medicare database to examine the extent to which intensive EOL-care patterns could explain EOL-care costs for dying patients with cancer. To wit, $49.2 \%$ received at least one intensive EOL-care intervention, which incurred substantially higher expenditures during the last $30 \mathrm{DOL}$, compared with not receiving such intensive care (US\$18 700 vs US\$4200, respectively; $p<0.001)$. Among those benefiting from at least one intensive EOL-care intervention, $71.3 \%$ of the EOL expenditures were for inpatient services. In contrast, palliative care was the primary expenditure for decedents not receiving any intensive EOL care (66.6\%). ICU admission appeared to be the major driver of EOL-spending differences.

\section{DISCUSSION}

The results of this systematic review synthesis showed that management of the EOL period differs among countries for patients with lung cancer. EOL-care aggressiveness is less intensive in Canada than the USA. ${ }^{36}$ This difference might reflect the differences in the healthcare systems of those two countries, cultural specificities, 
Table 4 Studies reports on end-of-life ICU admissions

\begin{tabular}{|c|c|c|c|c|}
\hline Study & $\begin{array}{l}\text { Patients, } \\
N\end{array}$ & Type of cancer & Inclusion criteria & $\%$ admitted to ICL \\
\hline \multirow[t]{2}{*}{ Mrad et $a l^{61}$} & 412496 & NSCLC & 1998 & 13.3 \\
\hline & & & 2014 & 27.9 \\
\hline \multirow[t]{2}{*}{ Presley et $\left.a\right|^{26}$} & 43654 & NSCLC & Veterans & 0.90 \\
\hline & & & Medicare beneficiaries & NR \\
\hline Ersek et a ${ }^{42}$ & 847 & NSCLC & Any & 25.40 \\
\hline Falchook et a/ ${ }^{32}$ & 12765 & Lung & Patient $<65$ years & 20.60 \\
\hline \multirow[t]{2}{*}{ Wu et $a l^{23}$} & 49920 & All & Palliative chemotherapy $<6$ months & 31.5 \\
\hline & & & Any chemotherapy & 6.5 \\
\hline Wright et $\left.a\right|^{14}$ & 1146 & All & Any & 13.20 \\
\hline \multirow[t]{2}{*}{ Wang et $a l^{52}$} & 82242 & All & 2005 & 15.30 \\
\hline & & & 2009 & 19.50 \\
\hline \multirow[t]{7}{*}{ Bekelman et a $/^{49}$} & 389073 & All & USA & 5.50 \\
\hline & & & The Netherlands & 7 \\
\hline & & & Belgium & 11 \\
\hline & & & Canada & 9.80 \\
\hline & & & UK & $N R$ \\
\hline & & & Germany & 3.50 \\
\hline & & & Norway & $N R$ \\
\hline \multirow[t]{2}{*}{ Choi et al ${ }^{30}$} & 263 & All & 2002 & 1.8 \\
\hline & & & 2012 & 19.9 \\
\hline Cheung et $a \beta^{31}$ & 107253 & All & Any & 5.5 \\
\hline \multirow[t]{2}{*}{ Amano et $a /^{58}$} & 266 & All & Early palliative care & 5.60 \\
\hline & & & SOC & 10 \\
\hline Zhang et $a^{/ 63}$ & 118 & NSCLC & Any & 25 \\
\hline Mack et al ${ }^{46}$ & 1231 & NSCLC and colorectal & Any & 9 \\
\hline \multirow[t]{2}{*}{ Ho et $a l^{37}$} & 227161 & All & 1993 & 3.06 \\
\hline & & & 2003 & 5.39 \\
\hline \multirow[t]{2}{*}{ Gonsalves et $a l^{44}$} & 200 & All & 2002 & 6 \\
\hline & & & 2008 & 33 \\
\hline \multirow[t]{2}{*}{ Keating et $\left.a\right|^{47}$} & 5826 & NSCLC and colorectal & VHA cohort & 12.50 \\
\hline & & & SEER cohort & 19.7 \\
\hline Tang et $\left.a\right|^{28}$ & 242530 & All & Trend 2000-2006 & 11.4 \\
\hline Temel et $a /^{36}$ & 46 & NSCLC & Integrated palliative care & 2 \\
\hline Barbera et $a /^{34}$ & 5855 & All & Any & 5.50 \\
\hline \multirow[t]{2}{*}{ Earle et $a l^{16}$} & 28777 & All & 1993 & 7.10 \\
\hline & & & 1996 & 9.40 \\
\hline
\end{tabular}

NR, not reported; NSCLC, non-small cell lung cancer;PBS, population-based study; SOC, standard of care; VHA, Veterans Health Administration.

doctors' usual practices. In the USA and Australia, doctors are encouraged to prescribe anticancer therapies, whereas in Canada, the national healthcare system no longer reimburses the cost beyond a certain number of chemotherapy lines.

This synthesis shows how difficult it is to compare the quality of EOL-care management because no global quality indicator exists. The most used criteria were developed by Earle et al. ${ }^{15} 16$ Among them, the most frequently analysed were recourse to chemotherapy during the last 14 or $30 \mathrm{DOL}$ and $\mathrm{ED}$ visits during the last 30 DOL. A growing body of data suggests that less use of palliative versus active chemotherapy for patients recognised as having short life expectancy or more frequent EOL discussions with them might reduce intensive EOL care and promote earlier access to palliative care, thereby improving the quality of EOL care of patients with advanced cancer. ${ }^{14-16} 232931496164$ Moreover, it was shown that EOL discussions might be particularly important for patients receiving palliative chemotherapy, who should be informed by substantiated scientific data of the likely outcomes associated with its use. ${ }^{6488}$ The EOL period should be prepared beforehand with the patient and his/her entourage. It was shown that family members' perceptions of EOL care of elderly patients who died of lung or colorectal cancer were associated with earlier palliative care enrolment, avoidance of ICU admissions during the last $30 \mathrm{DOL}$ and death outside the hospital. ${ }^{88}$ 
Table 5 Studies on the transition to palliative care during the last 3 days of life (DOL)

\begin{tabular}{|c|c|c|c|c|}
\hline Study & $\begin{array}{l}\text { Patients, } \\
N\end{array}$ & $\begin{array}{l}\text { Type of } \\
\text { cancer }\end{array}$ & $\begin{array}{l}\text { Inclusion } \\
\text { criteria }\end{array}$ & $\begin{array}{l}\% \text { Without } \\
\text { palliative } \\
\text { care } \\
\text { during the } \\
\text { last } 3 \text { DOL }\end{array}$ \\
\hline \multirow[t]{2}{*}{ Mrad et $\left.a\right|^{61}$} & 412496 & NSCLC & 1998 & 8.7 \\
\hline & & & 2014 & 53.0 \\
\hline Falchook et a $\left.\right|^{32}$ & 12765 & Lung & $\begin{array}{l}\text { Patients }<65 \\
\text { years }\end{array}$ & 54 \\
\hline Wright et al ${ }^{14}$ & 1146 & All & Any & 47.7 \\
\hline \multirow[t]{2}{*}{ Wang et $\left.a\right|^{52}$} & 82242 & All & 2005 & 7.2 \\
\hline & & & 2009 & 8.3 \\
\hline Mack et al ${ }^{46}$ & 1231 & $\begin{array}{l}\text { NSCLC } \\
\text { and } \\
\text { colorectal }\end{array}$ & Any & 42 \\
\hline Tang et $a^{28}$ & 242530 & All & $\begin{array}{l}\text { Trend 2000- } \\
2006\end{array}$ & 17.9 \\
\hline Temel et al ${ }^{\beta 6}$ & 46 & NSCLC & $\begin{array}{l}\text { Integrated } \\
\text { palliative care }\end{array}$ & 35 \\
\hline \multirow[t]{2}{*}{ Earle et a/ ${ }^{16}$} & 28777 & All & 1993 & 14.3 \\
\hline & & & 1996 & 17 \\
\hline
\end{tabular}

NSCLC, non-small cell lung cancer.

\section{Limitations of this study}

Limitations of this systematic review are those inherent with the methods used and the lack of data on this relatively new field of interest. In spite of the search strategy used, key papers may have been omitted. The two researchers extracted data only from the few available studies. A systematic review depends on existing and accessible evidence. When these are unavailable, insufficiently reported, biassed or of very poor quality, it may not be possible to draw definitive conclusions. Similarly, certain stages of systematic reviews imply a degree of subjectivity (selection of studies, evaluation of quality, narrative synthesis of results). In our case, very few prospective or interventional studies have been conducted. As of 29 May 2019, no study has been registered in ClinicalTrials.gov on EOL-care aggressiveness for patients with lung cancer. Because lung cancer management has changed dramatically over the last 15-20 years, we limited ourselves to studies published since 2000, which concerned patients treated during 1990-1995. Data from years prior to 1995 no longer correspond to current reality and we wanted to avoid biassing our analysis with no longer relevant findings. Similarly, grey literature was not included in our analysis because there are so few prospective studies or cohorts that the grey reports could be misleading with data not published in peer-reviewed journals.

Because the included studies were from resource-rich countries, with well-developed palliative care systems, generalisability of our findings to services in resourcepoor countries is limited. The types of studies retained for this analysis represent another limitation. Most of the data on the quality of EOL-care management come from medical administrative databases or retrospective studies. Few data are available from prospective studies or cohorts, which can lead to biassed analyses. In addition, only Earle $e \mathrm{al}^{16}$ considered all six validated criteria of EOL-care quality, while the other studies focused on only one to four of those indicators.

Among the other limitations of our review, we did not evaluate the studies for the risk of bias. Unfortunately, it is difficult to analyse the biases of each study because of the variety of types of studies retained. We also did not contact the authors to obtain individual lung cancer data for several reasons: first, we are not sure that they had analysed their data by type of cancer, and difficulty of obtaining individualised results could alter our results but it is known that lung cancer was included in most studies, and breast cancer is the most aggressively treated. The mix with other cancers probably weakens our results rather than strengthening them.

\section{Implications for clinical practice and future research}

Over time, a progressive trend towards higher percentages of patients receiving EOL care deemed aggressive was seen, probably because of the availability of enhanced numbers of therapeutic options and better tolerance of them. Those aggressive EOL treatments raised EOL-care costs, regardless of the healthcare system examined, without any significant benefit for the patient or his/ her family in terms of improved quality of life. ${ }^{89}$ Early access to palliative care lowered the number of patients given aggressive treatments. ${ }^{90}$ Unfortunately, in most healthcare systems, early access to palliative care during the course of these cancers remains limited. National or international research programmes should contribute to earlier and better identification of the factors supporting aggressive EOL-treatment interventions, and those favouring better palliative management of these patients.

\section{CONCLUSION}

Management of patients with lung cancer is complex, notably during the EOL period. The percentage of patients receiving aggressive EOL care continues to rise and it carries a non-negligible impact on healthcare costs. Prospective complementary studies are warranted to better discern the factors supporting aggressive EOL care and to evaluate early palliative care programmes.

Contributors OB, CC and MD have read and analysed all the studies. All authors participated in the writing of the manuscript.

Funding The authors have not declared a specific grant for this research from any funding agency in the public, commercial or not-for-profit sectors.

Competing interests None declared.

Patient consent for publication Not required.

Provenance and peer review Not commissioned; externally peer reviewed.

Open access This is an open access article distributed in accordance with the Creative Commons Attribution Non Commercial (CC BY-NC 4.0) license, which permits others 
to distribute, remix, adapt, build upon this work noncommercially, and license their derivative works on different terms, provided the original work is properly cited, appropriate credit is given, any changes made indicated, and the use is noncommercial. See: http://creativecommons.org/licenses/by-nc/4. $0 /$.

\section{ORCID iD}

Olivier Bylicki http://orcid.org/0000-0001-8683-0969

\section{REFERENCES}

1 Jemal A, Siegel R, Xu J, et al. Cancer statistics, 2010. CA Cancer J Clin 2010;60:277-300.

2 World Health organization. International agency for research on cancer. press release No. 223, latest world cancer statistics, 2013. Available: http://www. iarc.fr/en/media-centre/pr/2013/ pdfs/pr223_E.pdf

3 Fan H, Shao Z-Y, Xiao Y-Y, et al. Incidence and survival of nonsmall cell lung cancer in Shanghai: a population-based cohort study. BMJ Open 2015;5:e009419.

4 Aberle DR, Adams AM, National Lung Screening Trial Research Team,. et al. Reduced lung-cancer mortality with low-dose computed tomographic screening. N Engl J Med 2011;365:395-409.

5 National Cancer Institute, SEER Program. Seer STAT fact sheet: lung and bronchus cancer, 2014. Available: http://seer. cancer.gov/statfacts/html/

6 Cancer research UK. lung cancer survival statistics, 2013. Available: http://www.cancerresearchuk

7 Ettinger DS, Wood DE, Aisner DL, et al. Non-Small cell lung cancer, version 5.2017, NCCN clinical practice guidelines in oncology. J Natl Compr Canc Netw 2017;15:504-35.

8 Novello S, Barlesi F, Califano R, et al. Metastatic nonsmall-cell lung cancer: ESMO clinical practice guidelines for diagnosis, treatment and follow-up†. Ann Oncol 2016;27(suppl_5):v1-27.

9 D'Addario G, Früh M, Reck M, et al. Metastatic non-small-cell lung cancer: ESMO clinical practice guidelines for diagnosis, treatment and follow-up. Ann Oncol 2010;21 Suppl 5:v116-9.

10 Peters S, Adjei AA, Gridelli C, et al. Metastatic non-small-cell lung cancer (NSCLC): ESMO clinical practice guidelines for diagnosis, treatment and follow-up. Ann Oncol 2012;23 Suppl 7:vii56-64.

11 Earle CC, Landrum MB, Souza JM, et al. Aggressiveness of cancer care near the end of life: is it a quality-of-care issue? J Clin Oncol 2008;26:3860-6.

12 Zhang B, Nilsson ME, Prigerson HG. Factors important to patients' quality of life at the end of life. Arch Intern Med 2012;172:1133-42.

13 Teno JM, Curtis JR. Family perspectives on aggressive cancer care near the end of life. JAMA Oncol 2016;2:957-8.

14 Wright AA, Keating NL, Ayanian JZ, et al. Family perspectives on aggressive cancer care near the end of life. JAMA 2016;315:284-92.

15 Earle CC, Neville BA, Landrum MB, et al. Evaluating claimsbased indicators of the intensity of end-of-life cancer care. Int J Qual Health Care 2005;17:505-9.

16 Earle CC, Neville BA, Landrum MB, et al. Trends in the aggressiveness of cancer care near the end of life. JCO 2004;22:315-21.

17 Schnipper LE, Smith TJ, Raghavan D, et al. American Society of clinical oncology identifies five key opportunities to improve care and reduce costs: the top five list for oncology. J Clin Oncol 2012;30:1715-24.

18 Jacobson JO, Neuss MN, Hauser R. Measuring and improving value of care in oncology practices: ASCO programs from quality oncology practice initiative to the rapid learning system. Am Soc Clin Oncol Educ Book 2012:e70-6.

19 McNiff KK, Neuss MN, Jacobson JO, et al. Measuring supportive care in medical oncology practice: lessons learned from the quality oncology practice initiative. J Clin Oncol 2008;26:3832-7.

20 Neuss MN, Malin JL, Chan S, et al. Measuring the improving quality of outpatient care in medical oncology practices in the United States. JCO 2013;31:1471-7.

21 The patient protection and Affordable care act (PPACA).

22 Hutton B, Salanti G, Caldwell DM, et al. The PRISMA extension statement for reporting of systematic reviews incorporating network meta-analyses of health care interventions: checklist and explanations. Ann Intern Med 2015;162:777-84.

23 Wu C-C, Hsu T-W, Chang C-M, et al. Palliative chemotherapy affects aggressiveness of end-of-life care. Oncologist 2016;21:771-7.

24 S-C W, Chen J-S, Wang H-M, et al. Determinants of ICU care in the last month of life for Taiwanese cancer decedents, 2001 to 2006. Chest 2010;138:1071-7.

25 Rautakorpi LK, Seyednasrollah F, Mäkelä JM, et al. EndOf-Life chemotherapy use at a Finnish university hospital: a retrospective cohort study. Acta Oncol 2017;56:1272-6.

26 Presley C, Han L, O'leary J, O'Leary J, et al. Concurrent care and aggressive end-of-life lung cancer care. J Thorac Oncol 2017;12.

27 Kok PS, Chan H, Chao C, et al. 369OTiming of palliative care referral and its impact on receiving aggressive end of life care in patients with metastatic non-small cell lung cancer (NSCLC) in Southwest Sydney. Ann Oncol 2015;26(suppl 9):ix111.2-ix111.

28 Tang ST, Wu S-C, Hung Y-N, et al. Trends in quality of end-oflife care for Taiwanese cancer patients who died in 2000-2006. Ann Oncol 2009;20:343-8.

29 Greer JA, Pirl WF, Jackson VA, et al. Effect of early palliative care on chemotherapy use and end-of-life care in patients with metastatic Non-Small-Cell lung cancer. JCO 2012;30:394-400.

30 Choi Y, Keam B, Kim TM, et al. Cancer treatment near the end-of-life becomes more aggressive: changes in trend during 10 years at a single Institute. Cancer Res Treat 2015;47:555-63.

31 Cheung MC, Earle CC, Rangrej J, et al. Impact of aggressive management and palliative care on cancer costs in the final month of life. Cancer 2015;121:3307-15.

32 Falchook AD, Dusetzina SB, Tian F, et al. Aggressive end-of-life care for metastatic cancer patients younger than age 65 years. $J$ Natl Cancer Inst 2017;109.

33 Adam H, Hug S, Bosshard G. Chemotherapy near the end of life: a retrospective single-centre analysis of patients' charts. BMC Palliat Care 2014;13:26.

34 Barbera L, Paszat L, Qiu F. End-Of-Life care in lung cancer patients in Ontario: aggressiveness of care in the population and a description of hospital admissions. J Pain Symptom Manage 2008;35:267-74.

35 Sesé L, Didier M, Rousseau-Bussac G, et al. Chemotherapy at the end of life for patients with lung cancer. A practice analysis]. Rev Mal Respir 2015;32:256-61.

36 Temel JS, McCannon J, Greer JA, et al. Aggressiveness of care in a prospective cohort of patients with advanced NSCLC. Cancer 2008;113:826-33.

37 Ho TH, Barbera L, Saskin R, et al. Trends in the aggressiveness of end-of-life cancer care in the universal health care system of Ontario, Canada. J Clin Oncol 2011;29:1587-91.

38 Lee HS, Chun KH, Moon D, et al. Trends in receiving chemotherapy for advanced cancer patients at the end of life. BMC Palliat Care 2015;14.

39 Pacetti P, Paganini G, Orlandi M, et al. Chemotherapy in the last 30 days of life of advanced cancer patients. Support Care Cancer 2015;23:3277-80. 
40 Näppä U, Lindqvist O, Rasmussen BH, et al. Palliative chemotherapy during the last month of life. Annals of Oncology 2011;22:2375-80.

41 Murillo JR, Koeller J. Chemotherapy given near the end of life by community oncologists for advanced non-small cell lung cancer. Oncologist 2006;11:1095-9.

42 Ersek M, Miller SC, Wagner TH, et al. Association between aggressive care and bereaved families' evaluation of end-of-life care for veterans with non-small cell lung cancer who died in Veterans Affairs facilities. Cancer 2017;123:3186-94.

43 Henson LA, Gomes B, Koffman J, et al. Factors associated with aggressive end of life cancer care. Support Care Cancer 2016;24:1079-89.

44 Gonsalves WI, Tashi T, Krishnamurthy J, et al. Effect of palliative care services on the aggressiveness of end-of-life care in the veteran's Affairs cancer population. J Palliat Med 2011;14:1231-5.

45 Sano M, Fushimi K. Association of palliative care consultation with reducing inpatient chemotherapy use in elderly patients with cancer in Japan: analysis using a nationwide administrative database. Am J Hosp Palliat Care 2017;34:685-91.

46 Mack JW, Cronin A, Keating NL, et al. Associations between end-of-life discussion characteristics and care received near death: a prospective cohort study. J Clin Oncol 2012;30:4387-95.

47 Keating NL, Landrum MB, Lamont EB, et al. End-Of-Life care for older cancer patients in the Veterans health administration versus the private sector. Cancer 2010;116:3732-9.

48 Emanuel EJ, Young-Xu Y, Levinsky NG, et al. Chemotherapy use among Medicare beneficiaries at the end of life. Ann Intern Med 2003;138:639-43.

49 Bekelman JE, Halpern SD, Blankart CR, et al. Comparison of site of death, health care utilization, and hospital expenditures for patients dying with cancer in 7 developed countries. JAMA 2016;315:272-83.

50 Paiva CE, Valentino TCdeO, Paiva BSR. Impact of palliative care $(\mathrm{PC})$ on aggressive end-of-life (EOL) care indicators among advanced cancer patients (ACPS). JCO 2016;34(15 suppl).

51 Parekh HD, Tullio K, Elson P, et al. The effect of routine early palliative care (PC) consultation on aggressiveness of care at the end of life (EOL) in patients with advanced non-small cell lung cancer (NSCLC). JCO 2016;34(15_suppl).

52 Wang S-Y, Hall J, Long JB, et al. Trends and regional variation of end-of-life cancer care in the Medicare program. JCO 2015;33(15 suppl).

53 Warren JL, Barbera L, Bremner KE, et al. End-Of-Life care for lung cancer patients in the United States and Ontario. J Natl Cancer Inst 2011;103:853-62.

54 Yun YH, Kwak M, Park SM, et al. Chemotherapy use and associated factors among cancer patients near the end of life. Oncology 2007;72:164-71.

55 Hashimoto K, Yonemori K, Katsumata N, et al. Factors that affect the duration of the interval between the completion of palliative chemotherapy and death. Oncologist 2009;14:752-9.

56 Aragon-Ching JE, Cohen JB, Cohen A, et al. Chemotherapy at the end of life. Pro Am Soc Clin Oncol 2003;22.

57 Giorgi F, Bascioni R, Brungni M. Chemotherapy use at the end of life: decision making process. Pro Am Soc Clin Oncol 2004;23.

58 Amano K, Morita T, Tatara R, et al. Association between early palliative care referrals, inpatient hospice utilization, and aggressiveness of care at the end of life. J Palliat Med $2015 ; 18: 270-3$.

59 Andreis F, Rizzi A, Rota L, et al. Chemotherapy use at the end of life. A retrospective single centre experience analysis. Tumori 2011;97:30-4.
60 Tang ST, Wu S-C, Hung Y-N, et al. Determinants of aggressive end-of-life care for Taiwanese cancer decedents, 2001 to 2006. J Clin Oncol 2009;27:4613-8.

61 Mrad C, Abougergi MS, Daly B. One step forward, two steps back: trends in aggressive inpatient care at the end of life for patients with stage IV lung cancer. J Oncol Pract 2018:e746-57.

62 Kao S, Shafiq J, Vardy J, et al. Use of chemotherapy at end of life in oncology patients. Annals of Oncology 2009;20:1555-9.

63 Zhang B, Adelson KB, Velji S, et al. Characterization of aggressive intervention within 30 days of death in lung cancer patietn at Smilow cancer Hospital (SCH). J Clin Oncol 2014;32.

64 Wright AA, Zhang B, Keating NL, et al. Associations between palliative chemotherapy and adult cancer patients' end of life care and place of death: prospective cohort study. BMJ 2014;348.

65 Temel JS, Greer JA, Muzikansky A, et al. Early palliative care for patients with metastatic Non-Small-Cell lung cancer. $N$ Engl J Med 2010;363:733-42.

66 Sullivan AM, Lakoma MD, Matsuyama RK, et al. Diagnosing and discussing imminent death in the hospital: a secondary analysis of physician interviews. J Palliat Med 2007;10:882-93.

67 Chow E, Andersson L, Wong R, et al. Patients with advanced cancer: a survey of the understanding of their illness and expectations from palliative radiotherapy for symptomatic metastases. Clin Oncol 2001;13:204-8.

68 Matsuyama R, Reddy S, Smith TJ. Why do patients choose chemotherapy near the end of life? A review of the perspective of those facing death from cancer. JCO 2006;24:3490-6.

69 Silvestri G, Pritchard R, Welch HG. Preferences for chemotherapy in patients with advanced non-small cell lung cancer: descriptive study based on scripted interviews. BMJ 1998;317:771-5.

70 Mackillop WJ, Stewart WE, Ginsburg AD, et al. Cancer patients' perceptions of their disease and its treatment. $\mathrm{Br} \mathrm{J}$ Cancer 1988;58:355-8.

71 Agrawal M, Grady C, Fairclough DL, et al. Patients' decisionmaking process regarding participation in phase I oncology research. JCO 2006;24:4479-84.

72 Glare P, Virik K, Jones M, et al. A systematic review of physicians' survival predictions in terminally ill cancer patients. BMJ 2003;327:195-8.

73 Greer JA, Jackson VA, Meier DE, et al. Early integration of palliative care services with standard oncology care for patients with advanced cancer. CA A Cancer Journal for Clinicians 2013;63:349-63.

74 Wong AS, Teo C, Lim S-W, et al. Targeted therapy at the end of life for patients with lung cancer. J Palliat Med 2010;13:945-8.

75 Fujisawa D, Temel JS, Traeger L, et al. Psychological factors at early stage of treatment as predictors of receiving chemotherapy at the end of life. Psychooncology 2015;24:1731-7.

76 Saito AM, Landrum MB, Neville BA, et al. Hospice care and survival among elderly patients with lung cancer. J Palliat Med 2011;14:929-39.

77 Brooks GA, Cronin AM, Uno H, et al. Intensity of medical interventions between diagnosis and death in patients with advanced lung and colorectal cancer: a CanCORS analysis. J Palliat Med 2016;19:42-50.

78 Temel JS, Greer JA, El-Jawahri A, et al. Effects of early integrated palliative care in patients with lung and Gi cancer: a randomized clinical trial. J Clin Oncol 2017;35:834-41.

79 Henson LA, Gao W, Higginson IJ, et al. Emergency department attendance by patients with cancer in their last month of life: a systematic review and meta-analysis. JCO 2015;33:370-6.

80 Henson L, Gao W, Higginson I, et al. Emergency department attendance by patients with cancer in the last month of 
life: a systematic review and meta-analysis. The Lancet 2015;385(Suppl 1):S41.

81 Geraci JM, Tsang W, Valdres RV, et al. Progressive disease in patients with cancer presenting to an emergency room with acute symptoms predicts short-term mortality. Support Care Cancer 2006;14:1038-45.

82 DeVader TE, Albrecht R, Reiter M. Initiating palliative care in the emergency department. J Emerg Med 2012;43:803-10.

83 DeVader TE, Jeanmonod R. The effect of education in hospice and palliative care on emergency medicine residents' knowledge and referral patterns. J Palliat Med 2012;15:510-5.

84 Grudzen CR, Richardson LD, Hopper SS, et al. Does palliative care have a future in the emergency department? discussions with attending emergency physicians. J Pain Symptom Manage 2012;43:1-9.

85 Lamba S, Pound A, Rella JG, et al. Emergency medicine resident education in palliative care: a needs assessment. $J$ Palliat Med 2012;15:516-20.
86 Stone SC, Mohanty SA, Gruzden C, et al. Emergency department research in palliative care: challenges in recruitment. J Palliat Med 2009;12:867-8.

87 Cooke CR, Feemster LC, Wiener RS, et al. Aggressiveness of intensive care use among patients with lung cancer in the surveillance, epidemiology, and end Results-Medicare registry. Chest 2014;146:916-23.

88 Wright AA, Zhang B, Ray A, et al. Associations between end-of-life discussions, patient mental health, medical care near death, and caregiver bereavement adjustment. JAMA 2008;300:1665-73.

89 Teno JM, Connor SR. Referring a patient and family to high-quality palliative care at the close of life: "We met a new personality... with this level of compassion and empathy". JAMA 2009;301:651-9.

90 Triplett DP, LeBrett WG, Bryant AK, et al. Effect of palliative care on aggressiveness of end-of-life care among patients with advanced cancer. J Oncol Pract 2017;13:e760-9. 